\title{
The role of prophylactic anticonvulsants in moderate to severe head injury
}

\author{
Arshad Ali Khan • Ashis Banerjee
}

Received: 18 December 2009 /Accepted: 7 April 2010/Published online: 22 July 2010

(C) Springer-Verlag London Ltd 2010

\begin{abstract}
Background Post-traumatic seizures cause secondary brain injury, contributing to morbidity and mortality after traumatic brain injury. Seizure activity may be undetectable if the patient is paralysed and ventilated.

Aims The effect of prophylactic anticonvulsant therapy on the prevention of seizures after moderate to severe traumatic brain injury was studied.

Methods A structured systematic literature review was performed.

Results There may be a place for prophylactic anticonvulsants in the prophylaxis of early post-traumatic seizures.

Conclusion Further randomised controlled trials are needed to firmly establish the benefits of prophylactic anticonvulsants.
\end{abstract}

Keywords Head injury · Seizure · Anticonvulsants · Prophylaxis

\section{Introduction}

Trauma is an important cause of epilepsy. Post-traumatic epilepsy is defined as a recurrent seizure disorder due to traumatic brain injury. Post-traumatic epilepsy has become an important clinical problem in many countries, as the incidence of head injuries is steadily increasing, especially from road traffic accidents [1]. Post-traumatic epilepsy has been reported in $5-7 \%$ of all hospitalised patients with traumatic brain injury [2].

Disclaimer The views expressed in this paper are those of the author(s) and not those of the editors, editorial board or publisher.

A. A. Khan · A. Banerjee $(\bowtie)$

Chase Farm Hospital,

The Ridgeway,

Enfield EN2 8JL, UK

e-mail: libra19542003@yahoo.co.uk
Post-traumatic epilepsy can be divided into three groups: immediate seizure, occurring within $24 \mathrm{~h}$ of injury; early seizure, occurring within 7 days of injury; and late seizure, occurring more than 7 days after injury. The incidence of each following civilian head injury ranges from 1 to $4 \%, 4$ to $25 \%$ and 9 to $42 \%$, respectively [3].

Children are reported to have greater risk of early posttraumatic epilepsy as compared to adults after severe traumatic brain injury. The reported incidence of early post-traumatic epilepsy in children is $20-30 \%$ compared to $4-25 \%$ in adults. The incidence of late post-traumatic epilepsy in children is $7-12 \%$ as compared to $9-13 \%$ in adults.

In early post-traumatic epilepsy the peak incidence usually occurs within the initial $48 \mathrm{~h}$ of the causative head injury [4]. However, some seizures may escape clinical detection, and hence may be unnoticed in intubated paralysed patients in the absence of electroencephalography (EEG) monitoring. The presence of convulsive status epilepticus is associated with high mortality.

Effective prophylaxis of early post-traumatic seizures reduces brain metabolic demands, thereby reducing intracranial pressure and neurotransmitter release [5]. This in turn minimises secondary brain injury. Furthermore, anticonvulsant treatment can minimise cognitive and behavioural sequelae, and may have effects on future employment and recreation.

There are currently no internationally agreed guidelines available for the use of anticonvulsant prophylaxis for head injuries.

\section{Methods}

A literature search (primary search) was performed using the following databases:

- MEDLINE 1950 to 20 January 2010

- EMBASE 1974 to 20 January 2010

- CINAHL 1982 to 20 January 2010 
Additional sources included in the secondary search strategy were:

\section{The Cochrane Library}

2. References from relevant articles

3. Web-based resources:

(a) http://www.bestbets.org/

(b) http://www.google.co.uk/

(c) http://www.uptodate.com/

(d) http://www.clinicaltrials.gov/

Two randomised controlled trials (RCTs) were identified (Fig. 1), along with one meta-analysis (Fig. 2) and one systematic review (Fig. 3).

All studies were of high quality (level 1 and Jadad score 4/5). Temkin et al. (1990) conducted a double-blind, placebo-controlled trial at a level one trauma centre [6]. The primary end point of the study was the occurrence of seizure. This was a good study with clearly stated outcome and descriptions of randomisations, methods and double blinding. Inclusion and exclusion criteria were stated. There was no mention of power calculations; however, statistical analyses were described. The study was limited by rather small numbers in each group. Of the 586 patients assigned to treatment, 404 met the eligibility requirements. Of the eligible patients 208 were randomly assigned to the phenytoin group and 196 to the placebo group.

In this trial, serum levels of phenytoin were independently monitored and dosages were adjusted so that levels were maintained. A significant reduction in the incidence of early post-traumatic seizures in the treated group from 14.2 to $3.6 \%(p<0.001)$ was reported. The study presented convincing evidence of the effectiveness of phenytoin in preventing seizures in the first week after serious head injury.

Young et al. (2004) reported a limited randomised double-blinded, placebo-controlled trial investigating the use of phenytoin for the prevention of early posttraumatic seizures in children with moderate to severe head injury [7]. It was observed that there is a low rate of early post-traumatic seizures in children who had moderate to severe head injury and received standard critical care.

The review authors were unable to demonstrate a significant difference in the rate of early post-traumatic seizure between the phenytoin-treated and placebo-treated groups because of the small sample size and because phenytoin and benzodiazepines were used in the emergency department and paediatric intensive care unit (ICU). Another limitation of this study was many patients were intubated and ventilated in the paediatric ICU and were not monitored for subclinical post-traumatic seizures by using continuous electroencephalograms.
Schierhout and Roberts reported a systematic review in which they determined the effectiveness and safety of prophylactic anticonvulsants in the management of acute head injury [8]. Ten RCTs included patients with acute traumatic brain injury of all grades of severity. The subjects were assigned to either treatment or control groups on the basis of randomisation allocation. The authors of this review excluded the trials in which the intervention was started 8 weeks after injury. Relative risk and 95\% confidence intervals (CI) were calculated for each trial on an intention to treat basis. Heterogeneity between trials was tested using a $\chi^{2}$ test.

Seven RCTs in the review were conducted to assess the effect of anticonvulsants for the control of late seizures, and three were RCTs for early seizures. In all of the studies the three drugs used were phenytoin, carbamazepine and phenobarbitone. The studies regarding the treatment/prevention of early seizures used both carbamazepine and phenytoin, whereas for the treatment of late seizures, phenytoin and phenobarbitone were used.

The qualities of the trials analysed in this review ranged from 1 to 5 on the Jadad scale. The pooled relative risks for early seizures was 0.34 (95\% CI: $0.21-0.54 ; p=0.000)$. No beneficial effect of prophylactic anticonvulsant drugs was evident for mortality. The review recommended that anticonvulsant drugs may be used prophylactically in high-risk patients for the first week after injury.

Temkin (2001) conducted a meta-analysis, the purpose of which was to assess evidence concerning the effect of anticonvulsant drugs for seizure prevention, and to contrast their effectiveness for early and late seizures [3]. Inclusion criteria were clearly stated. Forty-eight studies were identified, and one was rejected; 14 studies with 15 drugs evaluated the effect of recurrences of febrile convulsion and 13 studies with 15 drugs to prevent post-traumatic seizures.

It was concluded that phenytoin prevents early seizures when administered within the first week after traumatic brain injury. Carbamazepine was also determined to be effective in the treatment/prevention of early seizures. Lorazepam was determined to prevent alcohol-related seizures, whereas verapamil was shown to have no role in prevention of early seizures.

\section{Discussion}

Seizures occur frequently after severe head injury and are often undiagnosed based on clinical examination only. The occurrence of post-traumatic epilepsy is medically and functionally an important complication of traumatic brain injury.

Immediate and early seizures are likely to have a different pathogenesis than late seizures. Closed head injury may lead to diffuse axonal injury with shearing of axons, 


\begin{tabular}{|c|c|c|c|c|c|}
\hline $\begin{array}{l}\text { Author, } \\
\text { Year, } \\
\text { Country. }\end{array}$ & $\begin{array}{l}\text { Study Design and } \\
\text { Level of Evidence. }\end{array}$ & $\begin{array}{l}\text { Patient Group } \\
\text { and Medications } \\
\text { Used. }\end{array}$ & Outcome Measures & Key Outcomes & Critical Appraisal \\
\hline $\begin{array}{l}\text { Temkin, } \\
\text { N.R. } \\
1990 \\
\text { USA } \\
\text { Level } 1 \\
\text { trauma } \\
\text { centre }\end{array}$ & $\begin{array}{l}\text { Randomised, double } \\
\text { - blind placebo Trial } \\
\text { Level } 1 \mathrm{~b} \\
\text { Jadad: } 4\end{array}$ & $\begin{array}{l}\text { Total 404: } \\
208 \text { phenytoin } \\
196 \text { placebo }\end{array}$ & $\begin{array}{l}\text { Seizures (early) } \\
\text { Adverse reactions. }\end{array}$ & $\begin{array}{l}\text { Phenytoin group had a } \\
\text { seizure rate of } 3.6 \pm 1.3 \\
\text { percent. } \\
\text { Placebo with } 14.2 \pm \\
\text { 2.6percent. } \\
(\mathrm{P}<0.001) \\
\text { Phenytoin treatment was } \\
\text { associated with a } \\
\text { decreased risk of seizure } \\
\text { in the first week. }\end{array}$ & $\begin{array}{l}\text { Inclusion and exclusion criteria stated. } \\
\text { Randomised method not stated. } \\
\text { Power calculation done. } \\
\text { Cox regression models used for powerful analysis. } \\
\text { Confidence interval measured. } \\
\text { Limited study sample. }\end{array}$ \\
\hline $\begin{array}{l}\text { Young, } \\
\text { K.D } \\
2003 \\
\text { USA }\end{array}$ & $\begin{array}{l}\text { Randomised, Double } \\
\text { - blind, Placebo } \\
\text { Controlled Trial. } \\
\text { Multi centre. } \\
\text { Level 1b. } \\
\text { Jadad: } 5\end{array}$ & $\begin{array}{l}102 \text { Patients: } \\
42 \text { given phenytoin } \\
56 \text { given placebo. }\end{array}$ & $\begin{array}{l}\text { Seizures and Adverse } \\
\text { reactions. } \\
\text { Occurrence of clinical or } \\
\text { electroencephalogram- } \\
\text { documented post- } \\
\text { traumatic seizures in } \\
\text { 48hours. }\end{array}$ & $\begin{array}{l}\text { Rate of early post- } \\
\text { traumatic seizure in } \\
\text { children with moderate to } \\
\text { severe was much lower. }\end{array}$ & $\begin{array}{l}\text { Inclusion and exclusion criteria stated. Randomisation and } \\
\text { method described in detail. Primary and secondary end- } \\
\text { points stated. } \\
\text { Statistical methods :Fishers exact test rank, Wilcoxon rank } \\
\text { sum test used. } \\
\text { Type } 1 \text { error and type } 2 \text { identified. } \\
\text { Study group was small. Study was incomplete. } \\
\text { Serum level of phenytoin was measured at the end of } \\
\text { observation period on patients who were admitted } \\
\text { EEG was not recorded to identify subclinical seizure. } \\
\text { In addition to phenytoin ,benzodiazepines used. }\end{array}$ \\
\hline
\end{tabular}

Fig. 1 Summary of randomised controlled trials

diffuse oedema and ischaemia leading to release of excitatory amino acids, cytokines, bioactive lipids and toxic mediators causing secondary cellular damage which leads to immediate and early seizures [8].
Post-traumatic seizures correlate with the extent of brain injury resulting from activation of a neurochemical cascade. Lipid peroxides, intracellular calcium ions, glutamate and free radicals are the major mediators for cell damage and

\begin{tabular}{|c|c|c|c|c|c|}
\hline $\begin{array}{l}\text { Author, } \\
\text { date and } \\
\text { country. }\end{array}$ & Methods. & $\begin{array}{l}\text { Number } \\
\text { of paper } \\
\text { included. }\end{array}$ & Search strategy. & Summary of results. & Comments. \\
\hline $\begin{array}{l}\text { Temkin, } \\
\text { N.R } \\
2001 \\
\text { USA }\end{array}$ & $\begin{array}{l}\text { Meta-analysis of } \\
\text { published papers. } \\
\text { The main aim was } \\
\text { to asses the role of } \\
\text { anti epileptic drug, } \\
\text { or drug } \\
\text { combination for } \\
\text { preventing } \\
\text { seizures associated } \\
\text { with fever, } \\
\text { alcohol, malaria, } \\
\text { traumatic brain } \\
\text { injury, and } \\
\text { tumours. }\end{array}$ & 48 & $\begin{array}{l}\text { Medline } \\
\text { EMBASE } \\
\text { Cochrane } \\
\text { controlled trials. } \\
\text { For traumatic } \\
\text { brain injury, } \\
\text { unpublished } \\
\text { studies were } \\
\text { identified through } \\
\text { meetings and } \\
\text { through informal } \\
\text { communications. }\end{array}$ & $\begin{array}{l}\text { Phenytoin prevents } \\
\text { provoked seizures } \\
\text { first week after } \\
\text { craniotomy and/or } \\
\text { traumatic brain } \\
\text { injury. } \\
\text { Carbamazepine also } \\
\text { effective in early } \\
\text { traumatic brain } \\
\text { injury. } \\
\text { Phenobarbitone is } \\
\text { effective in recurrent } \\
\text { febrile seizures. } \\
\text { No drug has been } \\
\text { shown to be effective } \\
\text { for provoked seizure } \\
\text { after one week. } \\
\text { Phenytoin is not anti- } \\
\text { epileptogenic, } \\
\text { but acts as a } \\
\text { suppressor of } \\
\text { seizures }\end{array}$ & $\begin{array}{l}\text { Inclusion criteria stated. } \\
\text { Studies included clear questions being asked. } \\
\text { Search strategy clearly stated. } \\
\text { Sample size of all studies not stated. } \\
\text { One trial was excluded from meta analysis, because } \\
\text { the outcome was the number of periods with } \\
\text { recurrences, and number of subjects with recurrences } \\
\text { could not be determined. } \\
\text { Relative risk mentioned. } \\
95 \% \text { confidence interval calculated. } \\
\text { Test for homogeneity for relative risk performed. } \\
\text { Fisher's exact test applied. }\end{array}$ \\
\hline
\end{tabular}

Fig. 2 Summary of meta-analysis 


\begin{tabular}{|c|c|c|c|c|c|}
\hline $\begin{array}{l}\text { Author, } \\
\text { date and } \\
\text { country. }\end{array}$ & Methods. & $\begin{array}{l}\text { Number } \\
\text { of paper } \\
\text { included. }\end{array}$ & Search strategy. & Summary of results. & Comments. \\
\hline $\begin{array}{l}\text { Schierhout, } \\
\text { G. } \\
1998 \\
\text { UK }\end{array}$ & $\begin{array}{l}\text { Systematic review } \\
\text { Aim was to } \\
\text { determine the } \\
\text { effectiveness and } \\
\text { safety of } \\
\text { anticonvulsants in } \\
\text { acute head injury }\end{array}$ & 10 & $\begin{array}{l}\text { RCT identified } \\
\text { using MEDLINE } \\
\text { 1950-1996, } \\
\text { EMBASE 1982- } \\
\text { 1986, CINAHL } \\
\text { 1982-1996. }\end{array}$ & $\begin{array}{l}\text { Anti-epileptic drugs } \\
\text { maybe used } \\
\text { prophylactically in } \\
\text { high risk patients } \\
\text { within the week of } \\
\text { injury. } \\
\text { No beneficial effect } \\
\text { of prophylactic } \\
\text { antiepileptic drugs } \\
\text { was evident for } \\
\text { mortality. }\end{array}$ & $\begin{array}{l}\text { Heterogeneity between the trials was tested. } \\
\text { Inclusion and exclusion mention, } \\
\text { Relative risk and } 95 \% \text { confidence interval were } \\
\text { calculated. } \\
\text { Qualities of the RCT range given. }\end{array}$ \\
\hline
\end{tabular}

Fig. 3 Summary of systematic review

death [10]. Patients with early seizures have a higher incidence of intracranial pathology.

Penetrating injury causes direct neuronal damage and is associated with post-traumatic epilepsy in $50 \%$ of cases. Non-penetrating head injury, including contusions and intracranial haemorrhages, is associated with posttraumatic epilepsy in up to $30 \%$ of cases. This is partially related to the toxic effect of haemoglobin breakdown (ferrous sulphate) on the neuron.

Reported risk factors for seizures include Glasgow Coma Scale score of less than 10/15, cortical contusions, depressed skull fractures, early intracranial haematoma, wounds with dural penetration, prolonged length of coma $(>24 \mathrm{~h})$ and prolonged length of post-traumatic amnesia $(>24 \mathrm{~h})$. The majority of early post-traumatic seizures occur within the first $24 \mathrm{~h}$.

Although genetic or predisposing factors have been assumed to be significant in addition to the severity of head injury in causation of post-traumatic epilepsy, the attempts to demonstrate a genetic influence have been inconclusive [7].

\section{Risk factors for developing post-traumatic seizures}

Glasgow Coma Scale (GCS) score $<10$

Cortical contusions

Depressed skull fracture

Subdural haematoma

Epidural haematoma

Intracerebral haematoma

Penetrating head wound
Factors which have been reported to lower the seizure threshold include cerebral ischemia, head injury (closed and penetrating), infection, metabolic disturbances, electrolyte imbalance, hypoglycaemia, $\mathrm{pH}$ disturbance, drugs, and hyperventilation. In case of severe head injury multiple factors are involved.

It is known that injury to any part of the brain may result in seizure, but the incidence is significantly greater when damage is in the region adjacent to the temporal sulcus. Loss or alteration in consciousness is the most reliable clinical indicator of acute brain damage. When focal damage is associated with prolonged loss of consciousness the susceptibility to seizure is increased. It is known that the epileptogenic process starts at the moment of trauma itself; and therefore intervention should start soon after the trauma, with the initial dose of prophylactic medication being administered within $1 \mathrm{~h} \mathrm{[9]}$.

Phenytoin, carbamazepine, sodium valproate and phenobarbitone have been demonstrated to be effective in the treatment of generalised tonic-clonic or partial seizures. Carbamazepine is an effective first-line agent for the prevention of tonic-clonic and partial seizures; however, carbamazepine is not available in the parenteral form, thereby limiting its practical use in the emergency department. Phenytoin has been shown to be effective in the prevention of early/immediate seizure when administered within the first week post-injury. It has also been shown to suppress tonic-clonic and complex partial seizures. Phenytoin is available in parenteral form and so is readily available for use in the emergency department. The loading dose of phenytoin is $18 \mathrm{mg} / \mathrm{kg}$ body weight. 
However, phenytoin is a negative inotrope and may cause hypotension; it may also interfere with coagulation function. The intramuscular route should not be used because absorption is unreliable and leads to crystallisation and abscess formation. When administered via the intravenous route, phenytoin should be given slowly to reduce the risk of cardiac arrhythmia and hypotension. Phenytoin may also lead to toxic epidermal necrolysis, and the drug should be stopped if a maculopapular erythematous rash is induced.

None of the drug treatments reviewed appear to prevent late seizures, regardless of the investigations and the type of the injury. For the above reasons as a general rule anticonvulsant drugs should only be used for prevention of immediate and early seizure after moderate to severe head injury.

Based on the available data, phenytoin can be justified as a short-term treatment option to prevent seizures occurring in the first week after trauma in high-risk patients, but not in low-risk patients.

\section{Conclusion}

Based on a systematic review of RCTs, meta-analyses and trial reports, it is concluded that prophylactic phenytoin reduces the incidence of seizure in the first week after injury but not thereafter. There is, therefore, potentially a role for phenytoin administered via the intravenous route in the suppression of early seizures in moderate to severe head injury.

Treatment should be ideally started within $1 \mathrm{~h}$ of injury, but is effective within the next $8 \mathrm{~h}$. This allows for delays in presentation, evaluation and transportation in individual cases. The available data indicate that the rate of early posttraumatic seizures in children is lower when compared to adults; however, the data were limited in scope. Therefore, there is a need for a larger multi-centre RCT to reliably determine the best course of treatment for children.

\section{References}

1. Beghi E (2003) Overview of studies to prevent posttraumatic epilepsy. Epilepsia 44(Suppl 10):21-26

2. Vespa PM, Nuwer MR, Nenov V et al (1999) Increased incidence and impact of nonconvulsive and convulsive seizures after traumatic brain injury as detected by continuous electroencephalographic monitoring. J Neurosurg 91:750-760

3. Temkin NR (2001) Antiepileptogenesis and seizure prevention trials with antiepileptic drugs: meta-analysis of controlled trials. Epilepsia 42:515-524

4. Grisar T, Bottin P, de Borchgrave d'Alténa V et al (2005) Prophylaxis of the epilepsies: should anti-epileptic drugs be used for preventing seizures after acute brain injury? Acta Neurol Belg 105:5-13

5. Brain Injury Special Interest Group of the American Academy of Physical Medicine and Rehabilitation (1998) Practice parameter: antiepileptic drug treatment of post-traumatic seizures. Arch Phys Med Rehabil 79:594-597

6. Temkin NR, Dikmen SS, Wilensky AJ et al (1990) A randomized, double-blind study of phenytoin for the prevention of posttraumatic seizures. N Engl J Med 323:497-502

7. Young KD, Okada PJ, Sokolove PE et al (2004) A randomized, double-blinded, placebo-controlled trial of phenytoin for the prevention of early posttraumatic seizures in children with moderate to severe blunt head injury. Ann Emerg Med 43:435446

8. Schierhout G, Roberts I (1998) Prophylactic antiepileptic agents after head injury: a systematic review. J Neurol Neurosurg Psychiatry 64:108-112

9. Teasell R, Bayona N, Lippert C et al (2007) Post-traumatic seizure disorder following acquired brain injury. Brain Inj 21:201-214

10. Brain Trauma Foundation, American Association of Neurological Surgeons, Congress of Neurological Surgeons et al (2007) Guidelines for the management of severe traumatic brain injury. XIII. Antiseizure prophylaxis. J Neurotrauma 24(Suppl 1):S83S86

Arshad Ali Khan is a specialty doctor in emergency medicine at Chase Farm Hospital, Enfield, and has previously worked as a registrar in neurosurgery.

Ashis Banerjee is a consultant and head of the Department of Emergency Medicine at Chase Farm Hospital, Enfield, and honorary senior lecturer at University College London Medical School. 